(RESEARCH ARTICLE)

\title{
Antiplasmodial activity of Anthocleista djalonensis leaves extracts against clinical isolates of Plasmodium falciparum and multidrug resistant K1 strains
}

\author{
Brice Kouakou Bla 1,*, Oléfongo Dagnogo ${ }^{1}$, Rolland Gueyraud Kipré ${ }^{1}$, Opportune Gogo Ballé ${ }^{1}$, Jonhson \\ David Trébissou ${ }^{1}$ and Joseph Allico Djaman ${ }^{1,2}$ \\ 1 UFR of Biosciences, University of Felix Houphouët Boigny, 22 BP 582, Abidjan 22. \\ ${ }^{2}$ Department of Clinical and Fundamental Biochemistry, Institute Pasteur of Cote d'Ivoire, 01 BP 490 Abidjan 01, Cote \\ d'Ivoire.
}

Publication history: Received on 01 December 2020; revised on 09 December 2020; accepted on 11 December 2020

Article DOI: https://doi.org/10.30574/wjarr.2020.8.3.0464

\begin{abstract}
Information collected from nine (09) traditional healers in the Moronou village in the Department of Toumodi revealed that Anthocleista djanlonensis is regularly used by the population for primary health care in the processing of malaria. Evaluation of the In vitro antiplasmodial activity showed that the aqueous extracts inhibit growth of clinical isolates and chloroquinoresistant strains (K1) with $\mathrm{IC}_{50}$ of $8.29 \mu \mathrm{g} / \mathrm{mL}$ and $10.23 \mu \mathrm{g} / \mathrm{mL}$ while the ethanolic extracts had IC 50 of $37.65 \mu \mathrm{g} / \mathrm{mL}$ and $46.07 \mu \mathrm{g} / \mathrm{mL}$ on the same strains respectively. Results of the In vitro antimalarial bioassay showed that aqueous extracts have promising antiplasmodial effects on clinical isolates and on Plasmodium falciparum multidrug resistant $\mathrm{K} 1$ strain $\left(3 \mu \mathrm{g} / \mathrm{mL}<\mathrm{IC}_{50}<15 \mu \mathrm{g} / \mathrm{mL}\right)$. Phytochemical screening revealed that the extracts contain mainly alkaloids, polyphenols, polyterpenes and flavonoids
\end{abstract}

Keywords: Medicinal plants; Toumodi, malaria; Phytochemical screening; Côte d'Ivoire; Anthocleista djalonensis

\section{Introduction}

According to the World Health Organization's Malaria Report, there were 228 million cases of malaria in 2018. The estimated number of malaria deaths stood at 405,000 in the same year [1]. The absence to date of an effective vaccine leaves us only chemotherapy to fight against Plasmodium falciparum infection, the most virulent Plasmodium species that infects humans. One of the problems of malaria control is the emergence and spread of P. falciparum strains that become resistant to almost all drugs available. Chloroquine (CQ) was one one of the used molecules in the fight against malaria because of its cost-effectiveness, but just some years after being placed on the market, the first cases of chloroquine resistance emerged in Southeast Asia, then in Latin America before spreading to all endemic areas [2]. Later, this phenomenon was repeated for the other available drugs (proguanil, sulfadoxine-pyrimethamine, halofantrine, mefloquine). To prevent, or at least delay the onset of new resistant strains, WHO recommended in 2001 the use of drugs association and that one of the drugs be an artemisinin derivative [3]. At that time, no artemisinin resistance had been identified yet and many hopes were placed onto artemisinins. Unfortunately, in 2008 Noedl et al. reported evidence of artemisinin resistance in Western Cambodia [4]. To date, artemisinin resistance has spread to Thailand, Myanmar, Laos and Vietnam [5, 6, 7]. Constituting a promising source of new drugs, medicinal plants have been given a priority interest worldwide in the search of safe and effective antiplasmodial agents from plants [8]. Artemisinin derivatives and cinchona alkaloids, such as quinine, are quite exemplary of such assertions. Studies conducted on several traditionally claimed Ivorian medicinal plants confirmed their antimalarial activities [9, 10]. Accordingly, the present study aimed at investigating the In vitro antimalarial activity of Anthocleista djolonensis, an important medicinal plant used in the Toumodi region for the treatment of malaria [11]. Anthocleista djalonensis is a

\footnotetext{
* Corresponding author: Brice Kouakou Bla

UFR of Biosciences, University of Felix Houphouët Boigny, 22 BP 582, Abidjan 22.
} 
woody plant 8-15 m high, growing on river banks. The leaves are 9-35 cm or even $1 \mathrm{~m}$ long, opposite, petiolate, with oval or elliptical blades. The flowers are grouped in long corymbs. Fruits are elliptic berries [12]. This study evaluated the In vitro antimalarial activity of aqueous extracts and $70 \%$ ethanol of A. djalonensis leaves against chloroquine-sensitive (CQ-S) NF54 and chloroquine-resistant (CQ-R) K1 strains.

\section{Material and methods}

\subsection{Collection and preparation of plant extract}

Fresh leaves of Anthocleista djalonensis A.Chev were collected in the Moronou village at the Department of Toumodi (Central Côte d'Ivoire) between July and September 2014. After identification at the National Floristic Center and a sample deposit at the herbarium, plant samples were air dried in shade at room temperature and ground into powder. Two times $100 \mathrm{~g}$ of the powder were macerated respectively in $1 \mathrm{~L}$ of distilled water and $1 \mathrm{~L}$ of $70 \%$ ethanol hydroalcoholic solvent using a blender. Macerates were filtered twice on hydrophilic cotton and once on Whatmann filter paper. Filtrates were evaporated through rotary vacuum evaporator and dried in an oven at $45^{\circ} \mathrm{C}$ for $48 \mathrm{~h}$ to obtain aqueous and hydroethanolic extracts which were stored at $4{ }^{\circ} \mathrm{C}$ for further use [13].

\subsection{Malaria parasites}

Informed consent was obtained from all patients in this study prior to clinical isolates collection. Four fresh clinical isolates of Plasmodium falciparum such as W6622, W6708, W6743 and W7177 were obtained from symptomatic patients at the Urban Health Unit (FSU-COM) of Wassakara in the district of Yopougon (Abidjan). Moreover, Plasmodium falciparum multidrug resistant K1 strain and Plasmodium falciparum chloroquine sensitive NF54 strains obtained from Medicine for Malaria Venture (MMV) were used for this study. The parasites were cultivated and maintained continuously in a human type 0 positive erythrocytes according to the method described by Trager and Jensen [14].

\subsection{In vitro antiplasmodial assay}

Culture medium was consisted of RPMI 1640 medium [supplemented with $12.60 \mathrm{~mL}$ HEPES (25 mM), $100 \mathrm{~mL}$ hypoxanthine, $312.5 \mathrm{lL}$ gentamycin $(40 \mathrm{mg} / \mathrm{mL})$ and glucose $(20 \mathrm{~g} / \mathrm{L}$, Wagtech $)]$. Symptomatic blood samples of patients collected in EDTA collecting tubes were centrifuged at $3000 \mathrm{rpm}$ for $5 \mathrm{~min}$, then blood serum and buffy coat were removed and blood pellet washed thrice in RPMI 1640 medium (Gibco USA) and diluted with uninfected human type 0 positive red blood cells to reach a parasitemia of $0.24 \%$ at $1.5 \%$ hematocrit. Thawing of Plasmodium falciparum K1 strain was performed according to the method described by Witkowski et al. (2013) [15]. After withdrawing the cryovial from the nitrogen liquid, it was left thawing inside the Biosafety hood Class II (STERILGUARD) and transferred in a Falcon tube $(15 \mathrm{~mL})$ and then centrifuged at $3000 \mathrm{rpm}$ for $5 \mathrm{~min}$. The supernatant was removed, an equal volume of $\mathrm{NaCl}(3.5 \%)$ was added dropwise to blood pellet and slowly stirred. The tube was left resting for $1 \mathrm{~min}$, then $12 \mathrm{~mL}$ of RPMI 1640 washing medium preheated at $37^{\circ} \mathrm{C}$ was added and centrifuged at $3000 \mathrm{rpm}$ for 5 min and the supernatant was removed. Then $50 \mu \mathrm{L}$ of the blood pellet was suspended in $8 \mathrm{~mL}$ of complete medium in a culture flask cells $(25 \mathrm{~mL}$, Nunc WVR) and a volume of $110 \mu \mathrm{L}$ of uninfected human type 0 positive red blood cells were added at $2 \%$ hematocrit. Daily, the infected blood pellets were transferred into fresh complete medium to propagate the culture. The stock solution of both crude extracts and Chloroquine were dissolved separately, $10 \mathrm{mg}$ of each substance in $10 \mathrm{~mL}$ of distilled water to obtain a concentration of $1 \mathrm{mg} / \mathrm{mL}$. Extract stock solutions were autoclaved at $121{ }^{\circ} \mathrm{C}$ for $15 \mathrm{~min}$ to sterilize them. As for reference molecules a $0.22 \mu \mathrm{m}$ Millipore filter was used for filtration. Aliquot of extracts and refence molecules were diluted in a complete medium and 100 of each aliquot was a twofold serial dilutions (100 $\mu \mathrm{L})$ were performed in a 96 well microplate and concentrations ranged from 100 to $1.56 \mu \mathrm{g} / \mathrm{mL}$ for crude extracts and from 1600 to $3.125 \mathrm{nM}$ for chloroquine. Plasmodium falciparum multidrug resistant K1 strains and Plasmodium falciparum chloroquine sensitive NF54 strains were synchronized by $10 \%$ D sorbitol (w/v) treatment at the ring stage prior to test. Then a volume of $100 \mu \mathrm{L}$ of the inoculum (parasitized erythrocytes) was added to each well to reach a final volume of 200 lL. Infected erythrocytes non-treated with drugs were used as negative control whereas infected erythrocytes treated with chloroquine (CQ) were used as positive control. All experiments were run in duplicate. Microplates were confined in a candle jar saturated with $\mathrm{CO}_{2}$ and incubated at $37{ }^{\circ} \mathrm{C}$ in an incubator for $72 \mathrm{~h}$. After $72 \mathrm{~h}$ of incubation, microplates were preserved at $-20^{\circ} \mathrm{C}$.

\subsection{Determination of $\mathrm{IC}_{50}$}

After thawing of the 96 well microplates $100 \mu \mathrm{L}$ of each well containing a volume of $200 \mu \mathrm{L}$ was transferred in a new 96 well microplate and $100 \mu \mathrm{L}$ of SYBR Green I lysis buffer ( $5 \mu \mathrm{L}$ of SYBR Green was mixed to $25 \mathrm{~mL}$ of lysis buffer) was added to each well using a multi-channel pipette and incubated in a dark room at $37{ }^{\circ} \mathrm{C}$ for 1 h. Fluorescence was measured with a spectro-fluorimeter BIOTEK microplate reader (BIOTEK, FLX 800) with excitation and emission 
wavelength bands centered at 485 and $530 \mathrm{~nm}$, respectively. $\mathrm{IC}_{50}$ (concentration of a tested substance inhibiting $50 \%$ of parasites growth) was determined through analysis of dose-response curves using the software IVART (In vitro Analysis and Reporting Tool) of WWARN [16].

\subsection{Phytochemical Screening}

Detection of major chemical groups was carried out according to the analytical techniques described by Tona et al. (1998) [17], Longanga et al. (2000) [18] improved by Békro et al. (2007) [19]. Phytochemical groups sought are essentially sterols, polyterpenes, alkaloids, tannins, polyphenols, flavonoids, quinones and saponins.Sterols and polyterpens.

\subsection{Sterols and polyterpenes}

Extracts $(0.1 \mathrm{~g})$ were dissolved in $1 \mathrm{~mL}$ of hot acetic anhydride in a capsule. The resulted solutions were poured and added with $0.5 \mathrm{~mL} \mathrm{H} 2 \mathrm{SO} 4$. A violet coloration that turned in blue, and then in green revealed the presence of sterols and triterpenes.

\subsection{Polyphenols}

A drop of alcoholic solution of $2 \%$ ferric chloride was added to $2 \mathrm{~mL}$ of extracts. A blue-blackish to green darkish coloration indicated a positive reaction.

\subsection{Flavonoids}

In a tube containing $3 \mathrm{~mL}$ of extract, a few drops of $10 \% \mathrm{NaOH}$ were added. Appearance of yellow-orange color indicated the presence of flavonoids.

\subsection{Catechic tannins}

Two milliliters of water and few drops of $1 \%$ ferric chloride were added to $1 \mathrm{~mL}$ of extract. The appearance of a blue, blue-black or black coloration indicated the presence of gallic tannins, the green or dark green coloration showed the presence of catechic tannins.

\subsection{Gallic tannins}

Previous solution was filtered and saturated with sodium acetate. Addition of 3 drops of 2\% FeCl3 causes appearance of an intense blue-black color denoting gallic tannins presence.

\subsection{Quinonic substances}

An aliquot ( $0.1 \mathrm{~g}$ ) of extract was dissolved in $5 \mathrm{~mL}$ of diluted $\mathrm{HCl}(1 / 5)$ and heated in a boiling water bath for $30 \mathrm{minutes}$, and then extracted with $20 \mathrm{~mL}$ of $\mathrm{CHCl} 3$ after cooling. To the organic phase was added $0.5 \mathrm{~mL}$ of $50 \% \mathrm{NH} 4 \mathrm{OH}$ diluted solution. The positivity of the reaction was indicated by a red to violet color.

\subsection{Alkaloids}

Two drops of Bouchard's reagent (reagent of iodine-iodide) were added to $1 \mathrm{~mL}$ of each extract. A red-brown precipitate indicated a positive reaction.

\subsection{Saponins (foam index)}

Samples ( $0.1 \mathrm{~g}$ of dry extract) were dissolved in $10 \mathrm{~mL}$ of distilled water. The samples were shaken vigorously up and down for 30-45 seconds and then left for 15 minutes. The height of the foam was measured. Persistent foam for more than $1 \mathrm{~cm}$ high indicated the presence of saponins.

\subsection{Characterization on thin layer chromatography (TLC)}

Analyses were carried out in the normal phase, with silica plates (Silicagel 60F254, 0.25 mm thick) deposited on aluminium sheets (stationary phase). On the prepared plates, $10 \mu \mathrm{L}$ of each extract was deposited. Then, the plates were introduced into glass vats previously saturated on the mobile phase (ethyl acetate+methanol+water 100:12:8). After development, the TLC plates were dried, observed under UV lamp and sprayed with reagents including 5\% methanolic potassium hydroxide, Godin and Dragendorff reagents. Plates were dried at $60{ }^{\circ} \mathrm{C}$ for 5 min and $110{ }^{\circ} \mathrm{C}$ for 10 min to 
reveal the spots resulting from the separation [20]. Each substance was identified by its fluorescence under UV light, by its frontal ratio (Rf) in a specific solvent system and by its colour after revelation with a specific reagent.

\subsection{Statistical analyses}

Graphics were performed using Graphpad prism 5 software (Microsoft, San Diego California, USA). All values were expressed as mean \pm Standard of deviation. Data analysis were performed using one way analysis of variance (ANOVA), followed by Tukey-Kramer multiple comparisms test using Graphpad instat@ software. Values were statistically significant at $\mathrm{p}<0.05$.

\subsection{Ethical consideration}

Informed consent was obtained from all patients enrolled in this study.

\section{Results and discussion}

\subsection{Results}

This study evaluated the anti-plasmodic activity of aqueous and ethanolic extracts from the leaves of Anthocleista djalonensis and qualitatively analyzed the chemical compound of these extracts.

\subsubsection{Preparation of extracts}

Decoction of water is the extraction method used by traditional healers to treat malaria. This technique was used to extract the bioactive compounds contained in Anthocleista djalonensis. The masses of the aqueous decoctate and that of the hydro-ethanolic organic extract are given in Table 1. The hydro-ethanolic and aqueous extracts gave yields of $8.8 \%$ and $7.5 \%$ respectively.

Table 1 Extraction report

\begin{tabular}{|l|l|l|l|}
\hline Solvent & Mass obtained & Yield (\%) & Appearance \\
\hline Water & $7,5 \mathrm{~g}$ & $7,5 \%$ & Light brown \\
\hline Ethanol & $8,8 \mathrm{~g}$ & $8,8 \%$ & Dark brown \\
\hline
\end{tabular}

\subsubsection{Phytochemical screening}

Phytochemical screening has shown that the solvents used solubilized several secondary metabolites. Alkaloids, polyphenols, polyterpenes, flavonoids and catechetic tannins were found to be present in both extracts with a predominance of polyphenols and alkaloids in the aqueous extract. Catechetical tannins and saponosides were absent in both extracts. The results of the phytochemical screening are reported in Table 2.

Table 2 Phytochemical screening of Anthocleista djalonensis leaves

\begin{tabular}{|l|l|l|l|l|}
\hline Chemical compound & Reaction/reagent & Coloration & Aqueous extract & Ethanolic extract \\
\hline Sterols/polyterpenes & \multicolumn{1}{|c|}{ LR } & Blue turns to green & + & + \\
\hline Polyphenols & \multicolumn{1}{|c|}{$\mathrm{FeCl}_{3}$} & Black bleu / Dark green & ++ & + \\
\hline flavonoids & $\mathrm{RC}$ & Orange-pink/Purplish & + & + \\
\hline catechic tannins & $\mathrm{SR}$ & Large flake precipitation & - & - \\
\hline gallic tannins & $\mathrm{FeCl}{ }_{3}$ & blue - black & + & + \\
\hline Quinones & $\mathrm{RBG}$ & red/purple & - & + \\
\hline \multirow{2}{*}{ alkaloids } & $\mathrm{DR}$ & orange & ++ & + \\
\cline { 2 - 5 } & $\mathrm{BR}$ & Reddish brown & + & + \\
\hline Saponosides & $\mathrm{FM}$ & 4 cm of Foam & - & - \\
\hline
\end{tabular}


$\mathrm{LR}=$ Liebermann reagent; $\mathrm{FeCl} 3=$ Ferric chloride; $\mathrm{RC}=$ Reaction to Cyanidine; $\mathrm{SR}=$ Stiasny reagent; $\mathrm{RBG}=\mathrm{Borntraëger}$ 's reagent; $\mathrm{DR}=$ Dragendorff's reagent; RB = Burchard's reagent; FM = Foam Test; $(++)$ = Positive reaction (abundant presence); $(+)=$ Positive reaction (weak presence); $(-)=$ Negative reaction (absence)

\subsubsection{TLC analysis}

Analysis of the chromatograms indicates that the aqueous extract contains only alkaloids and polyphenols. In fact, unlike Polyethylene Glycol, sulfuric vanillic acid and potassium hydroxide which gave a negative reaction, Dragendorff's reagent and iron trichloride showed a positive reaction by the respective appearance of orange color. On the other hand, the ethanolic extract contains in addition to these two compounds, quinones, flavonoids and terpenes in small quantities. Details of these results are shown in Table 3.

Table 3 Description of the chromatograms of the aqueous and ethanolic extracts of the leaves of Anthocleista djalonensis

\begin{tabular}{|c|c|c|c|}
\hline \multicolumn{4}{|c|}{ Alkaloids } \\
\hline & Color before reaction & color after reaction & Interpretation \\
\hline Aqueous extract & Light brown & Dark orange & Remarquable presence \\
\hline Ethanolic extract & Dark brown & orange & Presence \\
\hline \multicolumn{4}{|c|}{ Flavonoïdes } \\
\hline & Color before reaction & color after reaction & Interpretation \\
\hline Aqueous extract & Light brown & Light brown & Absence \\
\hline Ethanolic extract & Dark brown & yellow & Presence \\
\hline \multicolumn{4}{|c|}{ Quinones } \\
\hline & Couleur before reaction & color after reaction & Interpretation \\
\hline Aqueous extract & Light brown & & Absence \\
\hline Ethanolic extract & Dark brown & Pink under UV & Presence \\
\hline \multicolumn{4}{|c|}{ Polyphenols } \\
\hline & Color before reaction & color after reaction & Interpretation \\
\hline Aqueous extract & Light brown & brown & Remarquable presence \\
\hline Ethanolic extract & Dark brown & brown & Presence \\
\hline \multicolumn{4}{|c|}{ Terpenes } \\
\hline & Color before reaction & color after reaction & Interpretation \\
\hline Extrait aqueux & Light brown & Light brown & Absence \\
\hline Extrait éthanolique & Dark brown & Purple & Presence \\
\hline
\end{tabular}

\subsubsection{In vitro assessment of antiplasmodial activity}

The mean $\mathrm{IC}_{50}$ for clinical isolates in aqueous extract was $21.87 \pm 8.70 \mu \mathrm{g} / \mathrm{mL}$ with minimum and maximum $\mathrm{IC}_{50 \mathrm{~s}}$ of $8.29 \mu \mathrm{g} / \mathrm{mL}$ and $31.71 \mu \mathrm{g} / \mathrm{mL}$, respectively. This extract has an IC50 of $28.36 \mu \mathrm{g} / \mathrm{mL}$ on strain NF54 and $10.23 \mu \mathrm{g} /$ $\mathrm{mL}$ on K1. The aqueous extract exerts activity on all isolates and on the reference strains (Figure 1). The mean IC 50 of the ethanolic extract on clinical isolates was $42.29 \pm 3.76 \mu \mathrm{g} / \mathrm{mL}$ with respective minimum and maximum IC 50 of 37.65 $\mu \mathrm{g} / \mathrm{mL}$ and $47.91 \mu \mathrm{g} / \mathrm{mL}$. This extract has an $\mathrm{IC}_{50}$ of $48.30 \mu \mathrm{g} / \mathrm{mL}$ on strain NF54 and of $46.07 \mu \mathrm{g} / \mathrm{mL}$ on $\mathrm{K} 1$. Chloroquine has an $\mathrm{IC}_{50}$ of $12.8 \mathrm{nM}$ on strain NF54 and $114 \mathrm{nM}$ on K1. This molecule faces resistance (IC $50>100 \mathrm{nM}$ ) 
with isolate $\mathrm{W} 6622$. The mean $\mathrm{IC}_{50}$ of clinical artesunate isolates is $1.98 \pm 1.29 \mathrm{nM}$ with minimum and maximum IC50s of $0.61 \mathrm{nM}$ and $3.62 \mathrm{nM}$, respectively. The isolates and strain NF54 are susceptible to it. The mean IC 50 of clinical quinine isolates is $9.34 \pm 5.13 \mathrm{nM}$ with minimum and maximum $\mathrm{IC}_{50 \mathrm{~s}}$ of $3.06 \mathrm{nM}$ and $16.39 \mathrm{nM}$, respectively. The data from the In vitro sensitivity tests of the extracts and of the reference molecules on the clinical isolates and the strains NF54 and $\mathrm{K} 1$ are given in Table IV

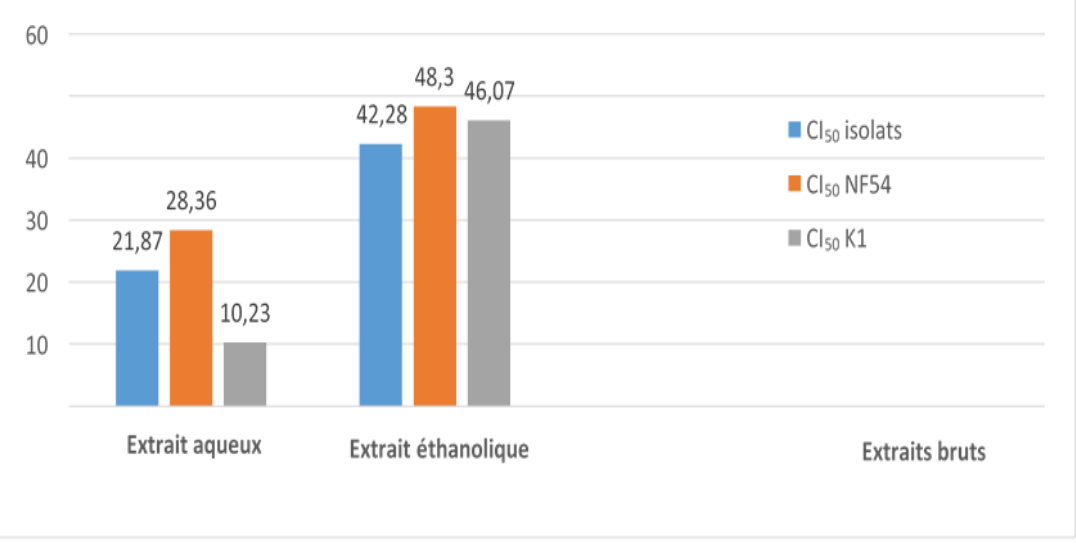

Figure $1 \mathrm{IC}_{50}$ of aqueous and ethanolic extracts on clinical isolates and reference strains NF54 and K1

Table 4 Inhibitory concentration $50 \%$ of extracts $(\mu \mathrm{g} / \mathrm{mL})$ and pure molecules $(\mathrm{nM})$ on clinical isolates and strains NF54 and K1

\begin{tabular}{|l|l|l|l|l|l|l|l|}
\hline & & \multicolumn{7}{|c|}{ IC50 drug } \\
\hline \multirow{3}{*}{} & & & $\begin{array}{l}\text { Aqueous } \\
\text { extract }\end{array}$ & $\begin{array}{l}\text { Ethanolic } \\
\text { extract }\end{array}$ & Chloroquine & Quinine & Artesunate \\
\hline \multirow{3}{*}{ Isolates } & \multirow{3}{*}{ CQ-S } & W6708 & 26,46 & 47,91 & 5,92 & 16,3 & 3,62 \\
\cline { 3 - 9 } & & W6743 & 31,71 & 37,65 & 16,22 & 11,94 & 2,89 \\
\cline { 3 - 9 } & W7177 & 21,04 & 40,53 & 12,04 & 6,07 & 0,83 \\
\cline { 2 - 9 } & CQ-R & W6622 & 8,29 & 43,06 & 106,39 & 3,06 & 0,61 \\
\hline \multirow{2}{*}{ Strain } & NF54 & 28,36 & 48,3 & 12,8 & 1,19 & 3,29 \\
\cline { 2 - 9 } & K1 & 10,23 & 46,07 & 114 & nd & nd \\
\hline
\end{tabular}

\subsection{Discussion}

The 70\% hydro-ethanolic solvent has a better extraction yield than the aqueous extract and contains more secondary metabolites. Chemical analysis showed that the aqueous extract consists predominantly of alkaloids and polyphenols, in abundant quantities, while the organic extract contains in addition to the two compounds, polyterpenes, flavonoids and anthraquinones. These results are similar to those obtained in Côte d'Ivoire by Kabran et al (2012) [21] and in Nigeria by Nduche et al (2015) [22] which showed that the ethanolic extract of A. djalonensis contains a variety chemical compounds including polyphenols, flavonoids and alkaloids. The abundance of alkaloids and polyphenols in the aqueous extract indicates that these compounds have a high affinity for water. The two extracts exhibit antiplasmodial activity on the four clinical isolates and on the two reference strains. An In vivo study carried out in Nigeria also showed that the ethanolic extract of the leaves of Anthocleista djalonensis had good activity on strains of Plasmodium berghei, comparable to the activity of 4 -aminoquinolines [23]. Another study evaluated the antiplasmodial and antipyretic activity of the roots of $A$. djalonensis on Plasmodium berghei and concluded that this plant has a prophylactic action and acts not only as a schizonticide but also as a usable antifolinic like pyrimethamine [24]. An earlier study demonstrated 
the efficacy of extracts from the leaves of this plant by comparing their antiparasitic activity to that of standard antibiotics [25].

These studies show that extracts of leaves of A. djalonensis have antiplasmodial potential and are a probable source of new bioactive compounds for the development of new antimalarials. However, the ethanolic extract, although having solubilized a greater number of secondary metabolites, has a very moderate activity tending towards the threshold of inactivity with an average IC 50 of $42.29 \pm 3.76 \mu \mathrm{g} / \mathrm{mL}$. This extract has an activity half as effective as that of the aqueous extract which has an $\mathrm{IC}_{50}$ of $21.87 \pm 8.70 \mu \mathrm{g} / \mathrm{mL}$. These results revealed that the aqueous extract has better antiplasmodial potential than the organic extract. The aqueous extract has an inhibitory effect on the In vitro growth of all clinical isolates, including the chloroquine resistant (CQ-R) isolate and K1 strain. This antiplasmodial activity could be explained by the abundant presence of alkaloids and polyphenols in this extract. A study conducted in Mali found that a decoction of Argemone mexicana L had an antimalarial efficacy comparable to that of artesunate-amodiaquine. Three alkaloids (allocryptopine, protopine and berberine) isolated from this plant were responsible for this activity against $P$. falciparum [26]. In Gabon, the antiplasmodial effect of the methanolic extract of Monodora myristica has been attributed to the alkaloids and polyterpenes present in this extract with an $\mathrm{IC}_{50}$ of $6.1 \mu \mathrm{g} / \mathrm{mL}$ [27].

An alkaloid is a natural organic compound, most often of plant origin, heterocyclic with nitrogen as a heteroatom, with a more or less basic complex molecular structure and endowed with pronounced physiological properties even at low doses. Alkaloids isolated from plants have antiparasitic properties and show antiplasmodial activity In vitro on Plasmodium falciparum with an $\mathrm{IC}_{50}=5 \mu \mathrm{g} / \mathrm{mL}$ and on certain resistant strains of Plasmodium falciparum [28]. Quinine, a natural antimalarial drug, effective against strains resistant to chloroquine, is an alkaloid. In 2012, a study showed that the alkaloidic extracts of Pyrostria major (Rubiaceae) and Gonioma malagasy (Apocynaceae), two plants from the Malagasy pharmacopoeia, showed quite remarkable antiplasmodial activity against the chloroquine-resistant strain FcB1 [29].

Polyphenols are a family of molecules with nearly 8,000 natural compounds. They have in common a benzene ring carrying at least one hydroxyl group. Phenolic compounds, natural antioxidants, show activity against a spectrum of parasites and have interesting antiplasmodic activities [30]. Two studies showed that the In vitro efficacy $($ IC $50=1.8 \pm$ $1 \mu \mathrm{g} / \mathrm{mL}$ ) of crude aqueous extracts from the stems and leaves of Chrozophora senegalensis (Euphorbiaceae) tested on chloroquine-resistant strains of $P$. falciparum was due to a polyphenol. This is very active on the trophozoite and young schizont stages while showing good prophylactic activity [31, 32]. A case of CQ-R was obtained with the W6622 isolate $\left(\mathrm{IC}_{50}=106.39 \mu \mathrm{g} / \mathrm{mL}\right)$ thus confirming the presence of chloroquine resistance in our country and helping to explain the disqualification of chloroquine as a first-line antimalarial in Côte d 'Ivoire [33].

The minimum $\mathrm{IC}_{50}$ of $3.06 \mathrm{nM}$ and maximum of $16.39 \mathrm{nM}$ obtained with quinine are far from its resistance threshold equal to $800 \mathrm{nM}$. These results confirm the good efficacy of this antimalarial, which remains one of the antimalarial drugs of last resort in the event of drug resistance or severe malaria. Since 1992, no quinino-resistant isolate has yet been detected in Côte d'Ivoire [34]. The $\mathrm{IC}_{50 \text { s }}$ obtained with artesunate, varying from $0.61 \mathrm{nM}$ to $3.62 \mathrm{nM}$, are below the threshold of $10 \mathrm{nM}$. These results confirm that artemisinin derivatives remain good antimalarial drugs and that resistance of $P$. falciparum to artemisinin has not yet been encountered in Côte d'Ivoire

\section{Conclusion}

Results from this study demonstrate the activity of Anthocleista djolonensis extracts against P. falciparum, the causative agent of malaria. To a reasonable extent, they also partly support the traditional uses of this plant in ethno-medicine to treat malaria. However, full validation of this use will depend on the results of detailed toxicological studies of the active extracts. The findings reported here have great scientific significance as they highlight for the first time the antiplasmodial activity of Anthocleista djolonensis in Côte d'Ivoire. Aqueous extracts with good antiplasmodial potential and selectivity against reference strains will be further fractionated following activity-guided approach, and the isolated hit compounds polished and progressed towards novel antimalarial drugs development.

\section{Compliance with ethical standards}

\section{Acknowledgments}

The authors thank sincerely the director of the health center of Yopougon Wassakara for having permitted this study. We are also grateful to the laboratory technicians for their assistance 


\section{Disclosure of conflict of interest}

The authors have none to declare

\section{References}

[1] WHO. Global malaria report. 2019; 232.

[2] Wellems T, Plowe C. Chloroquine-resistance malaria. Journal of Infectious Diseases. 2001; 184: 770-6.

[3] WHO. Antimalarial drug combination therapy. Report of a WHO technical consultation. Geneva: World Health Organization. 2001.

[4] Noedl H, Se Y, Schaecher K, Smith BL, Socheat D, Fukuda MM. Evidence of artemisinin-resistant malaria in Western Cambodia. The New England Journal of Medicine. 2008; 359: 2619-20.

[5] Phyo AP, Nkhoma S, Stepniewska K, Ashley EA, Nair S, McGready R, Moo C, Al-Saai S, Dondorp AM, Lwin KM, Singhasivanon P, Day NPJ, White J, Anderson JC Nosten F. Emergence of artemisinin-resistant malaria on the western border of Thailand: a longitudinal study. Lancet. 2012; 379: 1960-6.

[6] Kyaw MP, Nyunt MH, Chit K, Aye MM, Aye KH, Lindegardh N, Tarning J, Imwong M, Jacob CG, Rasmussen C, Perin J, Ringwald P, Nyunt MM. Reduced susceptibility of Plasmodium falciparum to artesunate in south- ern Myanmar. 2013; PLoS One, 8, e57689.

[7] Ashley EA, Dhorda M, Fairhurst RM, Amaratunga C, Lim P, Suon S, et al. Spread of artemisinin resistance in Plasmodium falciparum malaria. The New England Journal of Medicine. 2014; 371: 411-23.

[8] Willcox MLG. Bodeker G. Traditional herbal medicines for malaria. BMJ. 2004; 329: 1156-1159.

[9] Zirihi GN, Mambu L, Guede-Guina F, Bodo B, Grellier P. In vitro antiplasmodial activity and cytotoxicity of 33 West African plants used for treatment of malaria. Journal of Ethnopharmacology. 2005; 98: 281-5.

[10] Nkoua BC, Tano KD, Dable MT, Nsonde-Ntandou GF, Silue KD, Kouakou-Siransy G, Parra HJ, Menan H, Abena AA, Yavo W. Antiplasmodial activity and acute oral toxicity of Rauvolfia vomitoria leaves extracts, International Journal of Pharmacological Research. 2018; 8: 56-62.

[11] Bla KB, Trebissou JND, Bidie AP, Assi YJ, Zirihi GN, Djaman AJ. Étude ethnopharmacologique des plantes antipaludiques utilisées chez les Baoulé- N'Gban de Toumodi dans le Centre de la Côte d'Ivoire. Journal of Applied Biosciences. 2015; 85: 7775- 7783.

[12] Boullard B. Dictionnaire Plantes Médicinales du Monde - Réalités et croyances - Ed ESTEM. $2001 ; 636$.

[13] Zirihi GN, Kra AKM, Guédé-Guina F. Évaluation de l'activité antifongique Microglossa Pirifolia (Larmarck, O. Kuntze) (Asteraceae) « PYMI » sur la croissance In vitro de Candida albicans. Revue de Médecine et de Pharmacie. 2003; 17: 11-18.

[14] Trager W, Jensen JB. Cultivation of erythrocytic stages. Bulletin of the World Health Organization. 1977; 55: 363365.

[15] Witkowski B, Khim N, Chim P, Kim S, Ke S, Kloeung N, Chy S, Duong S, Leang R, Ringwald P, Dondorp AM, Tripura R, Benoit Vical F, Berry A, Gorgette O, Ariey F, Barale JC, MercereauPuijalon O, Menard D. Reduced artemisinin susceptibility of Plasmodium falciparum ring stages in Western Cambodia, Antimicrobial Agents and Chemotherapy. 2013; 57: 914-923.

[16] Le Nagard H, Vincent C, Mentre F, Le Bras J. Online analysis of In vitro resistance to antimalarial drugs through nonlinear regression. Computer Methods and Programs in Biomedicine. 2011; 104: 10-18.

[17] Tona L, Kambu K, Ngimbi N, Cimanga K, Vlietinck AJ. Antiamoebic and phytochemical screening of some Congolese medicinal plants. Journal of Ethnopharmacology. 1998; 61: 57-65.

[18] Otshudi AL, Vercruysse A and Foriers A. Contribution to the ethnobotanical, phytochemical and pharmacological studies of traditionally used medicinal plants in the treatment of dysentery and diarrhoea in Lomola area, Democratic Republic of Congo (RDC). Journal of Ethnopharmacology. 2000; 71: 411-423.

[19] Békro YA, Mamyrbekova-Békro JA, Boua BB, Tra-Bi FH, Ehilé EE. Étude ethnobotanique et screening phytochimique de Caesalpinia benthamiana (Baill.) Herend. et Zarucchi (Caesalpiniaceae), Sciences \& Nature. 2007; 4: 217-225. 
[20] Biallo D, Sanogo R, Yasambu H. Etude des constituants des feuilles de ziziphus mauritiana Lam. (Rhamnaceae). Chimie. 2004; 7: 1073-1080.

[21] Kabran GRM, Ambeu NC, Mamyrbékova-Békro JA, Békro YA. Phenols et flavonoïdes totaux dans les extraits organiques de dix plantes utilisees dans la traditherapie du cancer du sein en Côte d'Ivoire. European Journal of Scientific Research. 2012; 68: 182-190.

[22] Nduche MU, Edeoga HO, Omosun G Nwankwo D. Evaluation of the Chemical Composition of Five Nigerian Medicinal Plants. Journal of Pharmacy and Biological Sciences (IOSR-JPBS). 2015; 10: 27-31.

[23] Bassey AS, Okokon JE, Etim EI, Umoh FU Bassey E. Evaluation of the In vivo antimalarial activity of ethanolic leaf and stembark extracts of Anthocleista djalonensis. Indian Journal of Pharmacology. 2009; 41: 258-261.

[24] Akpan EJ, Okokon JE, Etuk IC. Antiplasmodial and antipyretic studies on root extracts of Anthocleista djalonensis against Plasmodium berghei. Asian Pacific Journal of Tropical Disease. 2012; 2: 36-42.

[25] Akinyemi AI Ogundare AO. Antibacterial Properties of the Leaf Extracts of Anthocleista djalonensis A. Chev on Some Pathogenic Organisms. European Journal of Medicinal Plants. 2014; 4: 75-85.

[26] Simoes-Pires C, Hostettmann K, Haouala A, Cuendet M, Falquet J, Graz B Christen P. pharmacology for developing an antimalarial phytomedicine. The example of Argemone mexicana. International Journal for Parasitology: Drugs and Drug Resistance. 2014; 4: 338-346.

[27] Lekana-Douki JB, Bongui JB, Liabagui SLO, Edou SEZ, Zatra R, Bisvigou U Kombila M. In vitro antiplasmodial activity and cytotoxicity of nine plants traditionally used in Gabon. Journal of Ethnopharmacology. 2011; 133: 1103-1108.

[28] Maïga A, Diallo D, Fané,S, Sanogo,R, Paulsen BS, Cissé B. A survey of toxic plants on the market in the district of Bamako, Mali: traditional knowledge compared with a literature search of modern pharmacology and toxicology. Journal of Ethnopharmacology. 2005; 96: 183-193.

[29] Beniddir AM, Martin MT, Dau MET, Grellier P, Rasoanaivo P, Guéritte F, Litaudon M. Goniomedines A and B: Unprecedented Bisindole Alkaloids Formed through Fusion of Two Indole Moieties via a Dihydropyran Unit. Organic letters. 2012; 14: 4162-4165.

[30] Froelich S, Schubert C, Bienzle U, Jenett-Siems K. In vitro antiplasmodial activity of prenylated chalcone derivatives of hops (Humulus lupulus) and their interaction with hemin. Antimicrobial Agents of Chemotherapy. 2005; 55: 883-887.

[31] Benoit-Vical F, Soha PN, Saléry M, Harguemb L, Poupat C, Nongoniermad R. Evaluation of Senegalese plants used in malaria treatment: Focus on Chrozophora senegalensis. Journal of Ethnopharmacology. 2008; 116: 43-48.

[32] Soh PN, Witkowski B, Olagnier D, Nicolau ML, Garcia-Alvarez MC, Berry A, Benoit-Vical F. In vitro and In vivo Properties of Ellagic Acid in Malaria Treatment. Antimicrobial. Agents and Chemotherapy. 2009; 53: 1100-1106.

[33] Trébissou JND, Yavo W, Tano KD, Dablé TM, Amiah AM, N'cho M. et Djaman AJ. In vitro Susceptibility to Atovaquone and Characterization of Pfcytb Gene of Plasmodium falciparum Isolates from Abidjan (Côte d'Ivoire). International Journal of Innovation and Applied Studies. 2014; 7: 1292-1297.

[34] Djaman J, Abouanou S, Basco L, Koné M. Limites de l'efficacité de la chloroquine et de la sulfadoxinepyriméthamine au nord de la ville d'Abidjan (Côte d'Ivoire): étude couplée In vivo/In vitro. Cahiers Santé. 2004; 14: 205-9208. 